\title{
The Legacy of the Reformasi: The Role of Local Government Spending on Industrial Development in a Decentralized Indonesia
}

Bangkit A. Wiryawan ( $\sim$ bangkit.aditya@gmail.com )

Nagoya University: Nagoya Daigaku https://orcid.org/0000-0001-7840-6914

Christian Otchia

GSID: Nagoya Daigaku Kokusai Kaihatsu Kenkyuka

\section{Research}

Keywords: decentralization, capital spending, local government, investment, industrial development

Posted Date: March 2nd, 2021

DOl: https://doi.org/10.21203/rs.3.rs-252105/v1

License: (c) (i) This work is licensed under a Creative Commons Attribution 4.0 International License.

Read Full License

Version of Record: A version of this preprint was published at Journal of Economic Structures on March 19th, 2022. See the published version at https://doi.org/10.1186/s40008-022-00262-y. 
The Legacy of the Reformasi: The Role of Local Government Spending on Industrial Development in a Decentralized Indonesia

Author 1 (corresponding author)

Bangkit A. Wiryawan

Graduate School of International Development, Japan

wiryawan.bangkit.aditya@g.mbox.nagoya-u.ac.jp

466-0852 Nagoya, Showa-ku Hagiwara-cho 3-28-1, Leo Palace 21 Kawan R. 203

Author 2

Christian Otchia

Graduate School of International Development, Japan

otchia@gsid.nagoya-u.ac.jp 


\title{
The Legacy of the Reformasi: The Role of Local Government Spending on Industrial Development in a Decentralized Indonesia
}

\begin{abstract}
Starting in 2001 the government of Indonesia employed Regional Autonomy law, providing larger fiscal role to the province and district governments. However, our understanding of its impacts on economic development of Indonesia is still limited. This paper seeks to find the relationship between increasing local government's capital expenditure on industrial development with focus in the non-oil and gas sector. Capital spending is thought to have moderation effect on investment, the main channel for industrialization, that should contribute to industrial growth. Our System GMM result suggests that there is significant correlation between capital spending and industrial growth. However, we fail to find significance moderation effect between local spending and investment towards the industry. Decentralization progress in Indonesia has been institutionally anchored by the central government particularly with the introduction of concurrent affairs in 2004, allowing central government to take a major developmental role at the local level. In the long run this contributes to the weakening capacity building at the local level, resulting in our non-positive findings. We propose a new institutional model that promote better central-local collaboration.
\end{abstract}

Keyword: decentralization, capital spending, local government, investment, industrial development

\section{Introduction}

Decentralization of government function can be best understood as the devolvement of decisionmaking from the central government to its lower tier-administration, as described by Litvack and Seddon (1999) in their Briefing Notes for the World Bank. This concept is supposed to bring Pareto growth efficiency according to early decentralization scholars (Tiebout 1956, Oates 1972). These first generation of theorists convinced decision-makers in developed countries, and thus propagating a wave of decentralization movement in the 1980s. However, in many developing countries the route to a decentralized governance institution has a quite different context. Large democratic movement in Brazil and the Philippines in the mid-1980s has led to a more decentralized institutions in both countries (Oxhorn et al. 2004). Indonesia followed the same narrative where the centralized-authoritarian rule of then president Soeharto met its end in 1998, provided a way for a more democratic bottom-up governance starting in 2001.

Government decentralization in Indonesia was part of the nation-wide reformasi ${ }^{1}$ program. This was done under the background of provincial discontent in around the time (Eaton et al.

\footnotetext{
${ }^{1}$ Reformasi is the Indonesian style of democratic and market reform, employed as a counter-narrative to the authoritarian and crony-capitalism characteristics of the Soeharto administration that lasted for over three decades. This concept deals directly with decentralization issue as it constitutes one of the six main agendas of reformasi.
} 
2011), specifically in the resource-rich regions. Starting in 2001, provinces and cities/districts are assigned larger fiscal roles that includes various governmental affairs excluding executive functions such as foreign and defense affairs. New provinces and cities were also established to meet this demand of a less-centralized state institution. Indonesian fiscal decentralization is complimented further when beginning in 2005 it further democratizes its sub-national tiers by introducing direct local elections. Figure 1 illustrates this change where the share of sub-national against general government spending increased dramatically from 2000 to 2003 during the early phase of decentralization, and then followed by steady increase until 2017. Consequently, in principle, the sub-national governments are granted larger decision-making abilities.

40

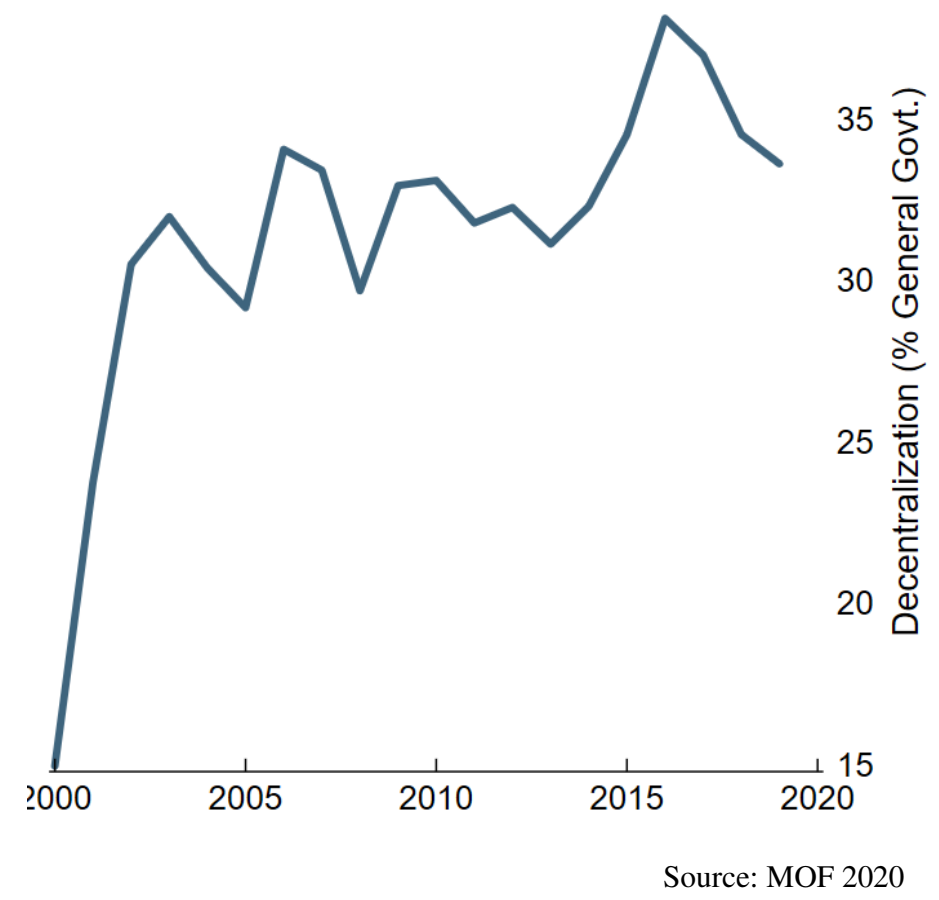

Fig. 1 Indonesia's Fiscal Decentralization share 2000 - 2019

However, it is important to notice that decentralization transition in Indonesia has not been smooth since the beginning. The transfer of authority from the central to the local government was done in a "big-bang" rush without much preparation and it was directed straight to the lowest level of government, districts and cities, bypassing the province (Nasution 2016). This illprepared decision created institutional problems ranging from corruption to the constant lack of capacity building at the local level as pointed out by various studies (Kuncoro 2006, Mulyo 2015, Nasution 2016, Alfada 2019).

Due to the lack of institutional quality at the local level in this first phase, Jakarta slowed down the pace of decentralization with the announcement of Law 32 in 2004. The law introduced the 'concurrent affairs' which allowed active presence of the central government at the sub-national level. Following the law, regulations were set up and various central government's agencies were re-established in provinces and cities. Some scholars perceived this as an effort to re-centralize political and administrative power (Rahmatunnisa 2015). In between the years, the government has also issued Law 28 on Local Tax that enabled local government to expand their tax base. This 
law has led to spiking numbers of local regulations in the following years. Despite all the dynamics, in political sense Indonesia is now a very much decentralized state compared to Soeharto's 'new order' era.

We expect that this dynamic institutional change would bring substantial effect on the economic performance at the local level. Indonesia's economic progress in the decades prior to this has been hailed as the 'rising tiger' due to its unprecedented high growth rate. The progression was largely sustained by export-driven manufacturing sector, before it was deeply affected by the 1997 Asian crisis. In the subsequent years, manufacturing share of total GDP had been decreasing, as well as its manufacturing trade specialization (Tijaja and Faisal 2014).

Scholars has been trying to link the impact of the new institutional arrangement on economic development. Setiawan and Aritenang (2019) found a positive impact of decentralization on regional economic growth optimally after three years. This confirmed the research of Dartanto and Brodjonegoro (2003), done in the early year of decentralization, who found out that decentralization is positively correlated with local economic growth and the effect is higher in the eastern region. In discussing about elite capture, a relevant issue that could affect development under decentralization, Chowdhury and Yamauchi (2010) revealed that village decentralization in Indonesia has not lead to elite capture but rather is representing community's interests. Contrasting arguments on the impact exists, that highlighted the negative or non-discernible effects of decentralization on economy (Pepinsky and Wihardja 2010, Lewis 2006, Kuncoro 2006).

So far neither of the studies above or any other studies exploits the impact of decentralization policy towards industrial development. Industrialization has been regarded as the key towards productive structural transformation. Developing countries are employing industrialization strategy to be able to catch-up with the developed ones. The success of the Newly Industrialized Countries of South Korea, Taiwan, Hong Kong, and Singapore are the famous case of this industrialization strategy by employing export-oriented approach. The same strategy employed by China, through its reform and opening-up (gaige kaifang) program in 1978 that paved the way towards an unprecedented sustained growth for multiple decades.

Considering its importance in sustaining growth and promote structural change, this paper seeks to find the impact of decentralization policy on industrial growth at sub-national level in Indonesia. We understand that theoretically, under neo-classical approach, investment serves as the main channel of industrial growth rather than government spending that are channeled through the local government. Therefore, we also consider the impact of investment; does higher local government spending expand or diminish investment's effect on industrial growth? How has the impact differed between various regions of the country?

The rest of this paper will discuss the literature review on decentralization in section 2, then followed with data description and estimation strategy in section 3. Results and discussion are presented in the section 4 and 5, respectively. Section 6 concludes our findings.

\section{Literature Review}

Arguments that support decentralization and economic growth has been started at least by $\mathrm{C}$. Tiebout (1956, 1961) and Oates (1972). Tiebout's mobile consumer model describes how increasing local budget in public service provisions can benefit individual consumer acrossjurisdiction by assuming a free-movement setting. This would incentivize local government as they could enjoy higher tax return. Oates, meanwhile, argues that fiscal federalism provides 
pareto-level efficiency as local government is closer to their constituents thus having deeper knowledge on local economic needs. These theories are influential and were the driving force behind decentralization wave occurred starting in 1980s. Subsequent body of works that support this optimistic view include Musgrave (1969), Weingast (1995) and Qian and Weingast (1997).

In a different manner with the optimistic perspectives above, Bahl and Nath (1986) using a sample of 57 developing countries, found that fiscal decentralization happened along with income growth. Thus, they suggested that for developing countries the policy is more appropriate for the middle and upper-middle income one. This is, however, not the only prerequisite. Wallich, Bird, and Ebel (1995) showed that missing institutional framework has been the source of inefficiency in developing-transitional countries of Eastern Europe. Their study was much related to the concern of institutionalist approach (Acemoglu and Robinson 2013; Acemoglu et al. 2008; North 1991). The lack of institutional quality in accompanying decentralization program then became the concern of the later decentralization scholars, (Junaid et al. 2005; Bird and Smart 2002; Azfar et. al. 1999; Litvack et al. 1998). Another institutional work includes also Treisman (1999; 2007) who revealed that there is no conclusively positive impact of decentralization on economic development for developing countries.

Numerous cross-country empirical evidence analyzing the impact of decentralization program on growth indicators show negative trends (Colombo and Martinez-Vazquez 2019; Davoodi and Zou 1998, Gemmell et al. 2013, Martinez-Vazquez and McNab 2003, RodriguezPose and Kroijer 2009, Ubago-Martínez et al. 2018, Yushkov, 2015). Meanwhile MartinezVazquez and McNab (2006) despite confirming the negative relationship on growth, they found that the effect is reduced through its positive impact towards macroeconomic stability, measured by consumer price index.

In the case of Indonesia, Kharisma (2013) and Kis-Katos and Sjahrir (2014) reveal that fiscal decentralization has brought positive impact on development. However for the latter work, in terms of political decentralization they concluded that there are no positive relationships on the public investment in the education, health, and infrastructure sectors. This means that local expenditures in these sectors does not depend on whether the district governments are democratically elected. Another study found out that local government in the post-2001 period was considered to be negatively affecting business, as argued by Kuncoro (2006). He found that firms failed to grow and descents to a process he called 'informalization' or downsizing in order to escape from paying local tax and bribes.

Further studies showed that Indonesian decentralization does not bring positive impact on economic performance (Pepinsky and Wihardja 2010). Their estimation method is unique as it involves the creation of synthetic "Indonesia" in which the country was not decentralized. They attributed the problem to local elite capture. On the other hand, Lewis's finding (2006) pointed out that the negative relationship is also due to local government's inefficiency in tax. This led to higher dependence on grant transfer from the central government.

These findings on Indonesia echo the concern of , Junaid et. al. (2005), and Nasution (2016) regarding the low capacity of the local government and that larger role of central government is needed.

\section{Data and Methodology}


Our analysis uses official data mainly from Statistics Indonesia (BPS). Missing variables due to the unavailability of data is expected when we designed this research. The following section discuss data measurement method and the descriptive statistics. Then it is followed by elaboration of our estimation strategy.

\subsection{Data}

Our main data source for the regional data on industry, trade, and inflation are derived from BPS, while investment data is coming from the Investment Coordinating Board of Indonesia (BKPM). We use foreign and domestic investments data on the industry sector. Table 1 presents the descriptive statistics of variables used in the analysis. Total number of observations amount to 544 , covering the time span of 16 years $(2004-2019)$ for 34 provinces. A new province established in 2012, North Kalimantan, is given imputed values to cover for the missing years. ${ }^{2}$

We use manufacturing (MAN) as the main proxy for the industry sector. The data is measured by calculating the share of manufacturing value added in the province level against the total Regional GDP of the said province. Opting to focus more on the labor-intensive activities, we exclude the mining industry sector from the data. This sector is thought to be more capital intensive yet engage in extractive activities that often oppose industrialization (dutch disease effect).

The BPS data source that we use is the yearly statistics of "GRDP of Provinces in Indonesia". The record provides information of GRDP by various industry sectors including agriculture and services. The mean value of MAN is $14.09 \%$ with $11.48 \%$ standard deviation.

Table 1. Descriptive Statistics

\begin{tabular}{llrrrrrc}
\hline Variable & Unit & Obs & Mean & $\begin{array}{r}\text { Std. } \\
\text { Dev. }\end{array}$ & Min & Max & Source \\
\hline \multirow{2}{*}{ MAN } & \% GDP & 544 & 14.09 & 11.48 & 0.77 & 67.24 & BPS \\
LCAP & \% Total Local Capital Exp. & 544 & 2.94 & 2.29 & 0.25 & 14.21 & BPS \\
FDI ${ }_{I N D}$ & Log Const. USD ‘000/capita & 544 & 1.94 & 1.70 & 0.00 & 6.00 & BKPM \\
DDI $I N D$ & Log Const. USD ‘000/capita & 544 & 1.70 & 1.43 & 0.00 & 5.69 & BKPM \\
GRDPPC & Log Const. USD ‘000/capita & 544 & 12.57 & 0.86 & 10.25 & 14.52 & WDI/BPS \\
TRADE & \% GDP & 544 & 94.16 & 46.72 & 17.53 & 326.48 & BPS \\
INFLATION & Annual \% & 544 & 6.42 & 4.20 & 0.02 & 29.34 & BPS \\
\hline
\end{tabular}

Data of local government spending is used to reflect on the increasing provinces' and districts' autonomy. However, we suspect that total local government spending is not the most appropriate measurement in estimating industrial development. Rather it is the capital spending of the local government (LCAP) that is a more appropriate measurement. Largely, this capital expenditure component consists of public investment expenditure such as for infrastructure development, but

\footnotetext{
${ }^{2}$ Our imputation method is based on Rubin's $(1987,1996)$ multiple imputation method. It is a predictive approach for handling missing data in a multivariate analysis and it uses both classical and Bayesian techniques (Zhu 2014).
} 
a lower share yet still substantial part of the budget goes also for the purchase of building and machineries to support routine civil service activities. The BPS publication source for this data, the yearly "Province Finance Statistics" and "District Finance Statistics", unfortunately does not separate between the two functions. Therefore, general capital spending is used here instead.

LCAP is measured by calculating the share of province and district government's capital spending against total local capital spending aggregated at the province level. Table 1 shows that the average share of capital expenditure for each province is at $2.9 \%$. Its standard deviation, which measures the distance between the observation, is at $2.3 \%$.

Investment data is differentiated based on its origin, whether they are foreign or domestic. The data provided by BKPM is the realization of investment data, meaning that the numbers went into the real sectors possibly contribute in generating fixed-capital formation in the provinces. Across 23 available sectors in 34 provinces, we selected investment in the non-oil and gas manufacturing sectors. These sectors include food and beverages, textile, pharmaceutical, transport, and machinery. We matched these selected sectors with our manufacturing industry data from the same sectors. Additionally, we also calculating per capita investment rather than using total value. This way we can control for the dominant effect coming from advanced region such as Jakarta and Java provinces.

The unit of measurement for these variables is in constant thousand USD, using national CPI data as the deflator. Domestic investment data is originally coming in IDR unit, but we adjust it to the USD using mid-yearly official exchange rate issued by BPS. As table 1 shows, foreign investment data (FDI ${ }_{I N D}$ ) has the mean $\log$ value of nearly 2, with standard deviation of 1.7. Several provinces at the beginning of decentralization transition phase, up to the end-2000s, received no FDI, especially in the manufacturing sector. Meanwhile, the domestic direct investment (DDI $I_{I N D}$ ) bear the mean value of 1.7, lower than its FDI ${ }_{I N D}$ counterpart, with 1.43 standard deviation.

\subsection{Estimation Strategy}

Unobserved heterogeneity is one of the main concerns in selecting our estimation method. This problem may occur from the missing variables in our dataset. As we briefly mentioned above, this problem is to be expected as only a handful of statistical data is available at the sub-national level. Therefore, we assume that applying a standard FE-OLS model will lead to a bias result.

Alternatively, a dynamic model is preferrable. In this case, the lag value of dependent variable is used in the regression. FE-OLS is not properly designed to control for endogeneity coming from the lagged dependent variable in the model, let alone with missing variables. System Generalized Method of Moment (GMM) is the more suitable estimation method for dynamic model. The model was first developed by and as an alternative to the previously developed estimation known as Difference-GMM.

The system GMM estimation uses two instrument equations, at the level and the first difference equation used in the Arellano and Bond method (Roodman, 2009). Our specification for system GMM equation is given as follow

$$
\begin{aligned}
& M A N_{i t}=\alpha M A N_{i t-1}+\beta_{1} L C A P_{i t}+\beta_{2} X_{i t}+\mu_{i t} \\
& \mu_{i t}=\eta_{i}+v_{i t}
\end{aligned}
$$

for $i=1, \ldots, N$ and $t=2, \ldots, T$, with $N>T$ with $\beta_{1}<1$ 
$M A N_{i t}$ denotes the non-oil and gas manufacturing share to GDP in the province $i, L C A P_{i t}$ is local government's capital spending aggregated at province level, $X_{i t}$ is a vector of exogenous control variables. $\mu_{i t}$ is the 'fixed effects' error term that can be decomposed into $\eta_{i}+v_{i t}$, assuming both are independently distributed across $i$ with the following error component structures (see Blundell and Bond 1998)

$$
\begin{array}{ll}
E\left(\eta_{i}\right)=0, E\left(v_{i t}\right)=0, E\left(v_{i t} \eta_{i}\right)=0 & \text { for } i=1, \ldots, N \text { and } t=2, \ldots, T \\
E\left(v_{i t} v_{i s}\right)=0 & \text { for } i=1, \ldots, N \text { and } \forall t \neq s
\end{array}
$$

We also consider the standard assumption of the initial condition of the dependent variable following Ahn and Schmidt (1995) as

$$
E\left(M A N_{i 1} v_{i t}\right)=0 \quad \text { for } i=1, \ldots, N \text { and } t=2, \ldots, T
$$

The orthogonality condition from equations (3) - (5), assuming that there is no serial correlation in the time-varying disturbances $v_{i t}$, is given as follow

$$
E\left(M A N_{i t-s} \Delta v_{i t}\right)=0 \quad \text { for } i=1, \ldots, N \text { and } t=2, \ldots, T
$$

Where $\Delta v_{i t}=v_{i t}-v_{i t-1}$. The equation can be simplified (Blundell and Bond 1998:118) into

$$
E\left(\boldsymbol{Z}_{i}^{\prime} \overline{\boldsymbol{u}}_{i}\right)=0
$$

Having instrument of equations at the level and first-difference in the model is thought to bring a risk of instrument proliferation problem. It is a condition where number of instruments tend to increase exponentially along with the number of time periods used (Heid Langer and Larch 2011). This would result in a finite sample bias and will likely to be overidentified. To overcome the problem, following Roodman (2009), we collapse the instrument matrix into single column. In order to check the validity of the model we apply the Hansen test, which is robust to a heteroskedastic condition.

Per capita GDP has thought to be one of the necessary control variables that should be included in growth estimation model, the other being investment level, population, and human capital (Levine and Renelt 1992). However, as decentralization concept in Indonesia is also based on the population size, having population variable in the model would create a multi-collinearity problem. Applying human capital variable in the model will also create the same problem. The investment variables, as described in the previous section, are differentiated based on its origin (FDI and DDI). Other necessary control variables used in the model are trade openness (\% GDP) and inflation (\% annual). 
Our per capita GDP variable (GRDPPC) is measured as log constant USD. The data is calculated using GDP data from World Development Indicator (WDI). Using the same data directly from BPS is problematic due to statistical discrepancy following the adoption of System of National Account in 2008, resulting in structural break in 2010.

\section{Result}

Our system GMM estimation results are divided into several parts; first we look at the initial impact without covariates before adding in the control variables and the interaction effects between local capital spending data and investments. Following this we proceed with heterogeneity analysis and robustness check. We bring the findings to formulate our arguments in the discussion part.

\subsection{Main results}

Table 2 reports the results under System GMM estimation. The one-step estimator is preferred following the argument that its asymptotic variance matrix is found to be more reliable than its two-step counterpart (Blundell and Bond 1998). On the first specification in column (1) shown in Table 2 we can see that the lagged value of dependent variable is positive and significant. The $\beta_{1}$ coefficient stands below 1, which suffices our assumption in equation (1). We can also see that the magnitude and sign are consistent across different specifications. This confirms the dynamic attribute of industrial development in post-reform Indonesia.

Coefficient of LCAP is positive and significant, presenting the evidence of local government's role in promoting the manufacturing sector. Based on the result we can then interpret that provinces with larger share of capital spending have higher manufacturing share with 0.09 coefficient. This effect seems to be small by itself but is not unexpected as fixed-capital formation is not the direct contributing factors to industrial production.

The initial result appears to be well justified judged by the post-estimation diagnostic result. We do not detect serial autocorrelation problem at the AR-2 level and the Hansen J-test result shows no sign of overidentifying restrictions as we failed to reject them. This suggests that the use of instruments in the model is justified.

We then proceed to check the robustness of our main result in column (1) to the presence of covariates. The magnitude of our target variable changed considerably. In specification (2) we can see that the coefficient of LCAP is now at 0.122 after controlling for GRDPPC. To control for any non-linearity relationship between GRDPPC and the dependent variable, we added its squared-term as a covariate. Negative correlation with GRDPPC in some of the specifications in Table 2 suggests a diversion of per capita growth from the industry sector. From the result, we can interpret that deindustrialization process is happening in many provinces in Indonesia. This result contradicts productive transformation theory. It is important to note, however, that these results are not statistically significant.

Furthermore, after controlling for $\operatorname{TRADE}_{(t-1)}$ and INFLATION in column (3) and (4) its coefficient changed slightly to 0.129 and 1.30 , respectively. The positive sign for TRADE is to be expected as it measures both inter-provincial imports and exports of tradable goods, that is 
dominated by manufacturing products aside of agricultural commodities. The same argument applies with INFLATION, which is positively correlated with MAN.

Table 2. Local Capital Spending and Industrial Development: Main Result

\begin{tabular}{|c|c|c|c|c|c|c|}
\hline \multirow{2}{*}{ VARIABLES } & \multicolumn{6}{|c|}{ DEPENDENT VARIABLE: MANUFACTURING } \\
\hline & (1) & (2) & (3) & (4) & $(5)$ & (6) \\
\hline $\operatorname{MAN}_{(\mathrm{t}-1)}$ & $\begin{array}{r}0.943 * * * \\
(0.026)\end{array}$ & $\begin{array}{r}0.955 * * * \\
(0.022)\end{array}$ & $\begin{array}{r}0.946 * * * \\
(0.023)\end{array}$ & $\begin{array}{r}0.950 * * * \\
(0.023)\end{array}$ & $\begin{array}{r}0.922 * * * \\
(0.028)\end{array}$ & $\begin{array}{r}0.927 * * * \\
(0.025)\end{array}$ \\
\hline LCAP & $\begin{array}{c}0.088^{*} \\
(0.048)\end{array}$ & $\begin{array}{r}0.122 * * * \\
(0.041)\end{array}$ & $\begin{array}{r}0.129 * * * \\
(0.046)\end{array}$ & $\begin{array}{r}0.130 * * * \\
(0.044)\end{array}$ & $\begin{array}{r}0.128 * * \\
(0.057)\end{array}$ & $\begin{array}{r}0.117 * * \\
(0.051)\end{array}$ \\
\hline RGDPPC & & $\begin{array}{r}-0.702 \\
(1.390)\end{array}$ & $\begin{array}{r}-0.262 \\
(1.569)\end{array}$ & $\begin{array}{r}-0.389 \\
(1.484)\end{array}$ & $\begin{array}{r}0.823 \\
(1.406)\end{array}$ & $\begin{array}{r}0.534 \\
(1.241)\end{array}$ \\
\hline RGDPPC $^{2}$ & & $\begin{array}{r}0.017 \\
(0.054)\end{array}$ & $\begin{array}{r}-0.002 \\
(0.061)\end{array}$ & $\begin{array}{r}0.002 \\
(0.058)\end{array}$ & $\begin{array}{r}-0.050 \\
(0.055)\end{array}$ & $\begin{array}{r}-0.039 \\
(0.049)\end{array}$ \\
\hline $\operatorname{TRADE}_{(t-1)}$ & & & $\begin{array}{r}0.003 * * \\
(0.001)\end{array}$ & $\begin{array}{l}0.003 * \\
(0.001)\end{array}$ & $\begin{array}{r}0.003 * * \\
(0.002)\end{array}$ & $\begin{array}{c}0.003 * \\
(0.002)\end{array}$ \\
\hline INFLATION & & & & $\begin{array}{r}0.057 * * \\
(0.024)\end{array}$ & $\begin{array}{r}0.055^{* *} \\
(0.025)\end{array}$ & $\begin{array}{r}0.058^{* *} \\
(0.025)\end{array}$ \\
\hline FDI $I N D$ & & & & & $\begin{array}{r}0.241 * * * \\
(0.065)\end{array}$ & $\begin{array}{r}0.216^{* * * *} \\
(0.058)\end{array}$ \\
\hline $\mathrm{DDI}_{I N D}$ & & & & & & $\begin{array}{c}0.074 * \\
(0.039)\end{array}$ \\
\hline CONS & $\begin{array}{r}0.518 \\
(0.381)\end{array}$ & $\begin{array}{r}6.418 \\
(9.003)\end{array}$ & $\begin{array}{r}3.824 \\
(10.070)\end{array}$ & $\begin{array}{r}4.509 \\
(9.521)\end{array}$ & $\begin{array}{r}-2.516 \\
(8.954)\end{array}$ & $\begin{array}{r}-0.821 \\
(7.876)\end{array}$ \\
\hline Province FE & Yes & Yes & Yes & Yes & Yes & Yes \\
\hline Year FE & Yes & Yes & Yes & Yes & Yes & Yes \\
\hline Observations & 544 & 544 & 544 & 544 & 544 & 544 \\
\hline Provinces & 34 & 34 & 34 & 34 & 34 & 34 \\
\hline Instruments & 35 & 37 & 38 & 39 & 40 & 41 \\
\hline AR-1 & 0.019 & 0.018 & 0.017 & 0.018 & 0.022 & 0.019 \\
\hline AR-2 & 0.240 & 0.239 & 0.231 & 0.321 & 0.236 & 0.232 \\
\hline Hansen (P-val) & 0.102 & 0.102 & 0.113 & 0.995 & 0.847 & 0.960 \\
\hline
\end{tabular}

Note: - Robust standard error in parentheses, $* \mathrm{p}<0.1, * * \mathrm{p}<0.05$, *** $\mathrm{p}<0.01$

- AR-1 and AR-2 denotes Arellano-Bond test with p-values results are reported. They are the necessary diagnostics for dynamic panel data estimation i.e. GMM.

- Hansen J-test calculates overidentifying restrictions that occurs due to increasing number of instruments. $\mathrm{P}$-value is reported.

As we include industrial investment variables into the model, coefficient of LCAP is getting smaller (column 5 and 6). We suspect that there are some moderation effects caused by these variables that jointly affect our dependent variable. The first investment variable is foreign investment (FDI ${ }_{I N D}$ ) and the second is domestic investment (DDI IND). The coefficients for both variables are positive and significant. Furthermore, their magnitude is one of the largest, which is to be expected as they are a direct factor for production. The domestic investment has 
considerably smaller coefficient than the foreign one, signifying that industrial development in Indonesia is linked more to FDI compared to DDI.

The interactional effect between LCAP and investment variables is presented in Table 3. Across all specifications, we apply the same control variables used in the previous table. Column (1) shows that despite the positive and significant partial terms of both LCAP and FDI ${ }_{I N D}$, their interaction terms are not positive. We also fail to see a positive interaction between LCAP and DDI ${ }_{I N D}$ despite the partial terms are also positive as shown in column (2).

Result shown in column (1) and (2) suffices the post-estimation diagnostics. The AR-2 p-value is not significant as well as our Hansen test.

Table 3. Local Capital and Industrial Development: Interaction Terms

Note: - Robust standard error in parentheses, ${ }^{*} \mathrm{p}<0.1,{ }^{* *} \mathrm{p}<0.05,{ }^{* * *} \mathrm{p}<0.01$

- AR-1 and AR-2 denotes Arellano-Bond test with p-values results are reported. They are the necessary diagnostics for dynamic panel data estimation i.e. GMM.

- Hansen J-test calculates overidentifying restrictions that occurs due to increasing number of instruments. P-value is reported.

\begin{tabular}{|c|c|c|c|c|c|c|c|c|}
\hline \multirow{2}{*}{ VARIABLES } & \multicolumn{8}{|c|}{ DEPENDENT VARIABLE: MANUFACTURING } \\
\hline & \multicolumn{2}{|c|}{ All } & $\begin{array}{c}\text { Non- } \\
\text { (3) }\end{array}$ & SAR & \multicolumn{2}{|c|}{ Resource rich } & Non-imputation & $\begin{array}{l}\text { utation } \\
\text { (8) }\end{array}$ \\
\hline MAN (t-1) & $\begin{array}{r}0.921 * * * \\
(0.027)\end{array}$ & $\begin{array}{r}0.953 * * * \\
(0.020)\end{array}$ & $\begin{array}{r}0.916 * * * \\
(0.025)\end{array}$ & $\begin{array}{r}0.941 * * * \\
(0.021)\end{array}$ & $\begin{array}{r}1.052 * * * \\
(0.008)\end{array}$ & $\begin{array}{r}1.052 * * * \\
(0.011)\end{array}$ & $\begin{array}{r}0.920 * * * * \\
(0.026)\end{array}$ & $\begin{array}{r}0.959 * * * \\
(0.019)\end{array}$ \\
\hline LCAP & $\begin{array}{r}0.140 * * * \\
(0.053)\end{array}$ & $\begin{array}{r}0.124 * * * \\
(0.041)\end{array}$ & $\begin{array}{r}0.176 * * * \\
(0.066)\end{array}$ & $\begin{array}{r}0.154 * * * \\
(0.057)\end{array}$ & $\begin{array}{r}0.158 * * \\
(0.067)\end{array}$ & $\begin{array}{r}0.134 * * \\
(0.064)\end{array}$ & $\begin{array}{r}0.155 * * \\
(0.061)\end{array}$ & $\begin{array}{r}0.145^{* * * *} \\
(0.048)\end{array}$ \\
\hline FDI $I N D$ & $\begin{array}{r}0.260^{* * * *} \\
(0.100)\end{array}$ & & $\begin{array}{r}0.272 * * * \\
(0.103)\end{array}$ & & $\begin{array}{r}0.272 * * \\
(0.124)\end{array}$ & & $\begin{array}{r}0.279 * * \\
(0.108)\end{array}$ & \\
\hline $\mathrm{DDI}_{I N D}$ & & $\begin{array}{l}0.098^{*} \\
(0.055)\end{array}$ & & $\begin{array}{l}0.097^{*} \\
(0.056)\end{array}$ & & $\begin{array}{r}0.103 \\
(0.178)\end{array}$ & & $\begin{array}{r}0.096 \\
(0.058)\end{array}$ \\
\hline LCAP x FDI IND & $\begin{array}{r}-0.005 \\
(0.017)\end{array}$ & & $\begin{array}{r}-0.007 \\
(0.018)\end{array}$ & & $\begin{array}{r}-0.024 \\
(0.018)\end{array}$ & & $\begin{array}{r}-0.007 \\
(0.019)\end{array}$ & \\
\hline LCAP x DDI IND & & $\begin{array}{r}-0.004 \\
(0.011)\end{array}$ & & $\begin{array}{r}-0.003 \\
(0.011)\end{array}$ & & $\begin{array}{r}-0.006 \\
(0.016)\end{array}$ & & $\begin{array}{r}-0.010 \\
(0.014)\end{array}$ \\
\hline CONS & $\begin{array}{r}-2.601 \\
(8.992)\end{array}$ & $\begin{array}{r}5.838 \\
(7.711)\end{array}$ & $\begin{array}{r}-7.268 \\
(11.883)\end{array}$ & $\begin{array}{r}-0.133 \\
(11.490)\end{array}$ & $\begin{array}{r}7.220 \\
(48.415)\end{array}$ & $\begin{array}{r}-37.457 \\
(58.613)\end{array}$ & $\begin{array}{r}-2.597 \\
(9.727)\end{array}$ & $\begin{array}{r}8.699 \\
(7.050)\end{array}$ \\
\hline Control Var. & Yes & Yes & Yes & Yes & Yes & Yes & Yes & Yes \\
\hline Province FE & Yes & Yes & Yes & Yes & Yes & Yes & Yes & Yes \\
\hline Year FE & Yes & Yes & Yes & Yes & Yes & Yes & Yes & Yes \\
\hline Observations & 544 & 544 & 464 & 464 & 96 & 96 & 512 & 512 \\
\hline Provinces & 34 & 34 & 29 & 29 & 6 & 6 & 32 & 32 \\
\hline Instruments & 41 & 41 & 41 & 41 & 41 & 41 & 41 & 41 \\
\hline AR-1 & 0.022 & 0.016 & 0.036 & 0.027 & 0.169 & 0.170 & 0.026 & 0.019 \\
\hline AR-2 & 0.246 & 0.364 & 0.213 & 0.398 & 0.948 & 0.791 & 0.197 & 0.257 \\
\hline Hansen (P-val) & 0.849 & 0.980 & 0.999 & 0.999 & 1.000 & 1.000 & 0.973 & 0.998 \\
\hline
\end{tabular}




\subsection{Additional results}

To check the strength of our result shown in Table 3, subsequent heterogeneity analysis is performed. Firstly, we try to exclude all of the Special Administrative Regions (SARs) from the model. These provinces are Nangroe Aceh Darussalam (Aceh), Jakarta Capital Region, Yogyakarta Special Region, West Papua, and Papua province. The reason to exclude them is because these provinces have different institutional settings than the others. Their institutional differences varies, which also influenced by political history and localities.

Jakarta Capital Region differs with other provinces as it does not have politically elected district government. The city is headed by a Governor who appoints six administrative mayors with little decision-making power. Thus, the administration is more centralized than other provinces. Secondly, as the capital region much attention is given from the central government. This contributes to its higher fiscal and human capital resources. Thirdly, historically Jakarta has always been the important economic center of Indonesia. ${ }^{3}$ This further accumulate resources in the area and created large gaps with other urban economic agglomeration in the country.

In the other special regions distinct institutional setting also exists. In Yogyakarta Special Region, the province is led by a Sultan who held its position hereditary, thus it is not democratically elected unlike other provinces. Meanwhile in Aceh, the special autonomy given to this region allows them to set up Islamic-based law that is not widely applicable to the other provinces, thus making it difficult to compare. Lastly, in the Papua and West Papua provinces, they enjoyed higher fiscal transfer from Jakarta in the form of General Allocation Grant (DAU) and Special Allocation Grant (DAK), along with specialized local representative council (Majelis Rakyat Papua) consisted of indigenous people. The council has the ability to set up ethnic-based rules. Like in Aceh and Yogyakarta, these institutional characteristics are not found in the other provinces. Thus, removing these four provinces and Jakarta from our estimations are justified.

After removing the Special Administrative Regions (SAR), we can see in column (3) and (4) that the coefficient of LCAP improved slightly, with the magnitude of the investment variables improved. Coefficient for FDI ${ }_{I N D}$ changed slightly from 0.260 to 0.272 while DDI ${ }_{I N D}$ coefficient almost does not change. However, despite the partial interaction terms positive and significant, we found no positive let alone significant interactions.

We further check our result by altering our specification, keeping the resource rich provinces in the model. Those provinces are Aceh, Riau, East Kalimantan, West Kalimantan, Papua and West Papua. The selection is based on the share of oil and gas rent against their respective RGDP. The result showed in column (5) and (6) stated that the coefficient for LCAP improved slightly from the original specifications. The partial interaction terms are still positive and significant except for DDI ${ }_{I N D}$. The interaction terms, however, still not showing any positive signs. These results, however, must be carefully accepted as it suffers from overidentifying restrictions with the implausibly high Hansen test p-value result (1.000) for both of the specifications. This might occur due to the now lower number of cross-sectional dimensions that violated the large $\mathrm{N}$ and small $\mathrm{T}$ principle for dynamic panel data estimation.

\footnotetext{
${ }^{3}$ Jakarta's prominent status as economic and administrative center has long history. In the early $17^{\text {th }}$ century, the Dutch East Indies Company (VOC) moved their trading post from the more prosperous Banten region to the neighboring Jakarta bay area, As the Banten Empire weaken, Jakarta emerge as the region's economic hub. The later Dutch Colonial Government and the present Indonesian Government continued to base their administrative and economic activities on the city.
} 
Finally, we extend our analysis by dropping the imputed province and the outlier, which are North Kalimantan and Bengkulu. Dropping these provinces serves double purpose, to increase the initial validity of our model and to justify the use of our imputation. The result can be found in Table 3 column (7) and (8). The signs do not change and coefficient magnitudes are consistent with the previous specifications with the two provinces included.

\subsection{Robustness Check}

We estimated our main result on Table 3 using System GMM which is known for its better handling of endogeneity that is coming from both lagged value of dependent variable and unobserved heterogeneity. Despite that, we would like to apply robustness test using different estimation methods. Table 5 shows this result. On the column (1) and (2), OLS result is presented. There we found that LCAP is positive and significant, and so does FDI but not DDI, but again none of the interactions are positive and significant.

Our FE-OLS result on column (3) and (4) depart from the previous model, showing significance only for FDI $I N D$ and the interaction is negative and significant. Lastly, difference GMM estimation (column 5 and 6) shows the closest result to our System GMM (column 7 and 8), with LCAP, FDI $I_{I N D}$, and DDI $I_{I N D}$ are positively correlated with industrial growth but with no significant interaction terms.

\section{Discussion}

The result showed that local capital expenditure, by itself, has positive impact on industrialization. Districts and provinces with larger share of capital spending have higher marginal effect on the sector's growth. However, simply looking at this relationship without addressing the more important channel of industrialization would result in poor analysis. Therefore in this research we felt the need to assess the impact of investments, and its interaction with local capital spending.

The negative interactional terms across all specifications suggest that with every percentage increase of local government's capital spending, the positive impact of FDI IND and DDI IND towards industrial growth would diminish by $0.004-0.005$ percent. The effects are considerably small and not significant, yet the signs are consistent. The results brought up earlier discussions raised by Nasution (2016) that highlighted the weak capacity of the local governments. They have not been able to provide efficient public service that would translate directly in supporting the industry sector. Similar issue was also raised by previous studies (Mulyo 2015, Pepinsky 2010, Lewis 2006).

Weak capacity of the local government has been an inherent problem in Indonesia. Decadeslong centralized administration under Soeharto has impaired much of local institutional capacity. Given this condition, the sudden liberalization of provinces and districts government following the 1999 regional autonomy law has failed to encourage growth. Increasing responsibilities that comes with fiscal and political decentralization outweigh their ability and capacity. Consequently, local government has not been able to expand their revenue base, further limit their development role. Development of institutional capacity was also very low as well.

Under these circumstances the local government relied to Jakarta for assistance. Their budgetary structure composed of large transfer allocated by the Ministry of Finance. At the district level, the share of central government transfer to their own budget was as much as 90 percent in 
2001. Meanwhile, their own-source revenue constitutes only 7 percent of their revenue (Nasution 2016).

The central government resolved this capacity gap by introducing the 'concurrent affairs' with the law 2004 on regional government, which further strengthened in 2014. This paved the way for the reintroduction of central government programs and agencies at the local level. For proponent of regional autonomy, this was viewed as a re-centralization effort (Rahmatunnisa 2015). However, this move has been in line with previous literatures addressing the lacking capacity of local government (Bird and Smart 2002; Junaid et al. 2005). On the one hand, the change had helped in increasing districts' and provinces' revenue by 4 and 11 percent, respectively. But on the other hand, the share of capital expenditure has been decreasing by 16 and 3 percent.

The increasing revenue reflects the growth on the productive sector, while the decreasing share of capital expenditure reflects their low capacity and over dependance to Jakarta. Under the concurrent affairs scheme, the central government handled major connectivity projects that linked intra-provincial areas, while local government covers inter-provincial regions. However, local government often seek for central government's assistance to undertake inter-provincial projects, giving further impression of ailing local capacity.

Lastly, it also worth to note that development gap at the local level is not the only reason for the increasing role of central government. Jakarta's concern was also raised by the evidence of local elite-capture problems following the regional autonomy law, which has been observed by several studies (Lucas 2016; Firdaus 2018). This problem further prevented capacity building at the local level and justified the recentralization attempt.

The initial attempt by Jakarta was to reduce the development gap at the local level that was mainly caused by the weak capacity of the local government and Jakarta's concern over local elite-capture. The resulting over reliance on the central's role also served as a constraint for local government. In the short run the policy could be justified to resolve some institutional issues but on the long run it diverted from the main objective of the 'reformasi' which is to ensure regional autonomy to the sub-national governments.

Based on our findings, we therefore suspect that larger positive interaction on industrial growth is mostly coming from the central government's intervention. Jakarta's enormous effort on infrastructure development, especially in the last two administrations of Susilo Bambang Yudhoyono and Joko Widodo, contributed to the sustained growth from 2004 to 2019. The positive impact of local capital expenditure on industry is perceived as a complimentary effect of the central government.

Improving the relationship between local capital spending and investment for the benefit of industrial development will remain a major challenge. This burden might be too big of a task for district governments to handle. The decision to dumped fiscal budget directly to the districts in the early phase of decentralization (2001-2003) has contributed to this problem, as they do not possess the capacity. As described previously, the central government later opted to intervene at the sub-national level.

There are several steps that could be done to improve local government's capital spending efficiency in this area. First, Jakarta needs to reformulate their 'concurrent affairs' strategy. The current strategy of central-local collaboration does not require significant role of local government thus it has not improved their capacity significantly, as suggested by our findings. Rather than 
direct intervention separately between the central affairs and local affairs, i.e. in infrastructure development, they should promote more collaborations with the local governments beyond the said affairs. Secondly, a more direct hands-on role should be given to the local government with the central government provide assistances. These would help in increasing the latter's capacity, especially at the district level. Thirdly, from the local government side, a reformulated development role as suggested above would require them to increase capital spending. Accordingly, they also need to reallocate their budgetary spending to emphasis more capacity development programs.

In order to make this plan work, a significant institutional change would need to be done. In addition to the "concurrent affairs" that separated the central and local government, a new function that allow central-local collaborative work should be introduced. This change would require a political will from all key stakeholders, particularly the central government who needs to increasingly involve and encourage the local government in development process whilst carefully consider local institutional readiness.

\section{Conclusion}

Following major economic and political reform in 1998, the Government of Indonesia introduced regional autonomy bill in 2001 that effectively increased larger role of the local government. This research attempts to unveil the impact of provinces' and districts' expenditure on industrial development. To this end, we extend our analysis by exploring the relationship with foreign and domestic investments. Using province and district-aggregated data, our System GMM estimation found that larger local capital spending correlates positively with the industry sector. This finding is robust across different specifications. However, we fail to find a positive and significant interaction between local capital spending and investment. If anything, our result showed a negative tendency. This suggests that with every percentage increase of local governments' capital spending, the positive impact of foreign and domestic investment is marginally decreasing. We suspect that larger positive impact that channeled investment on industrial growth is coming from the central government's expenditure.

In a decentralized Indonesia, issues regarding local government capacity remained a major institutional challenge. The decision to push for deep decentralization in the early period (2001 2004) exacerbated this situation, lead to Jakarta's intervention through the second decentralization law that introduced 'concurrent affairs'. This intervention, in turns, created over-dependency towards the central government, resulting in the negative interaction effect in our finding. To improve this condition, we argue that the central government need to formulate a new institutional strategy that allows for a central-local collaboration, stressing more direct role for the local governments. The current model gives too dominant role for the central government in economic related affairs i.e. infrastructure development, and the function is carried out separately between central and local. The collaborative strategy is also meant to improve local governments' capacity through budget reallocation and Jakarta's assistance in development projects. Achieving this, however, require political will especially from the central government who need to incrementally devolve their function to the local government assuming a certain institutional quality has been met. Future research could complement our finding by studying the distributional impact of central government's expenditure towards industrial development. 


\section{Reference}

Acemoglu D, Johnson S, Robinson, JA, Yared, P (2008) Income and democracy. American Economic Review 98(3):808-842. Doi: 10.1257/aer.98.3.808

Acemoglu D, Robinson, J A (2013) Why nations fail: the origins of power, prosperity, and poverty Why nations fail the origins of power, prosperity and poverty. Profile, London.

Ahn SC, Schmidt, P (1995) Efficient Estimation of Models for Dynamic Panel-Data. J of Econometrics 68(1):5 -27. Doi: 10.1016/0304-4076(94)01641-C

Alfada, A (2019) Does Fiscal Decentralization Encourage Corruption in Local Governments? Evidence from Indonesia. J of Risk and Financial Management 12(3). Doi: Artn $11810.3390 / \mathrm{Jrfm} 12030118$

Arellano M, Bond S (1991) Some Tests of Specification for Panel Data - Monte-Carlo Evidence and an Application to Employment Equations. Review of Economic Studies 58(2):277297. Doi: $10.2307 / 2297968$

Arellano M, Bover O (1995) Another Look at the Instrumental Variable Estimation of ErrorComponents Models. J of Econometrics 68(1):29-51. Doi: 10.1016/03044076(94)01642-D

Azfar O, Kähkönen S, Lanyi A, Meagher P, Rutherford D, (1999) Decentralization, Governance and Public Services: The Impact of Institutional Arrangements. A Review of the Literature: IRIS Center, University of Maryland.

Bird RM, Smart M (2002) Intergovernmental fiscal transfers: International lessons for developing countries. World Development 30(6): 899-912. Doi: 10.1016/S0305-750x(02)00016-5

Blundell R, Bond S (1998) Initial Conditions and Moment Restrictions in Dynamic Panel Data Models. J of Econometrics 87(1).

Chowdhury S, Yamauchi F (2010) Has Decentralization in Indonesia Led to Elite Capture or Reflection of Majority Preference? JICA Research Institute, Tokyo.

Colombo DG, Martinez-Vazquez J (2019) Fiscal Decentralization and Public R\&D Policy: A Country Panel Analysis: International Center for Public Policy. Georgia State University, Atlanta.

Dartanto T, Brodjonegoro BP (2003) Dampak Desentralisasi Fiskal di Indonesia Terhadap Pertumbuhan Ekonomi dan Disparitas Antar Daerah: Analisa Model Makro Ekonometrik Simultan. J Ekonomi dan Pembangunan Indonesia, 4(1):17-38

Davoodi H, Zou H F (1998) Fiscal decentralization and economic growth: A cross-country study. J of Urban Economics 43(2): 244-257. Doi: 10.1006/juec.1997.2042

Eaton K, Kaiser K, Smoke P (2011) The Political Economy of Decentralization Reforms. The World Bank, Washington, DC.

Firdaus S (2018) Fenomena Elite Capture dalam Pengelolaan Badan Usaha Milik Desa (BUMDes): Studi kasus bekerjanya kekuasaan elite dalam pengelolaan BUMDes Argosari, desa Pulosari, Kabupaten pemalang. J Ilmu Politik 9(2):20-37. doi: https://doi.org/10.14710/politika.9.2.2018.20-37

Gemmell N, Kneller R, Sanz I (2013) Fiscal decentralization and economic growth: Spending versus revenue decentralization. Economic Inquiry 51(4). Doi: 10.1111/j.14657295.2012.00508.x

Kuncoro A (2006) Decentralization and Corruption in Indonesia: Manufacturing Firms Survival under Decentralization (Vol. 25). The International Centre for the Study of East Asian Development, Kitakyushu.

Levine R, Renelt D (1992) A Sensitivity Analysis of Cross-Country Growth Regressions. American Economic Review 82(4):942-963.

Kharisma B (2013). Desentralisasi Fiskal dan Pertumbuhan Ekonomi: Sebelum dan Sesudah Era Desentralisasi Fiskal di Indonesia. Jurnal Ekonomi dan Studi Pembangunan, 14(2), 101 119. 
Litvack J, Seddon J (1999). Decentralization Briefing Notes. In J. Litvack \& J. Seddon (Eds.), WBI Working Papers. The World Bank, Washington, DC.

Litvack, J, Ahmad J, Bird RM (1998). Rethinking decentralization in developing countries PREM. The World Bank, Washington, DC.

Lucas, A (2016). Elite Capture and Corruption in two Villages in Bengkulu Province, Sumatra. Human Ecology, 44(3), 287-300. doi: 10.1007/s10745-016-9837-6

Wallich C, Bird RM, Ebel RD (1995). Decentralization of the Socialist State: Intergovernmental Finance in Transition Economies. International Bank for Reconstruction and Development/The World Bank, Washington, DC.

Lewis BD (2006) Local government taxation: An analysis of administrative cost inefficiency. Bulletin of Indonesian Economic Studies, 42(2):213-233. Doi: $10.1080 / 00074910600873666$

Martinez-Vazquez J, McNab RM (2003) Fiscal decentralization and economic growth. World Development 31(9):1597-1616. Doi: 10.1016/S0305-750x(03)00109-8

Mulyo SA (2015) Decentralization in Indonesia: an empirical analysis of district and city performance. In: Otsubo S (ed) Globalization and Development Volume III: In search of a new development paradigm (1st ed.) Routledge, London, pp. $114-141$.

Musgrave RA (1969) Theories of Fiscal Federalism. Public Finance 24(4):521-536.

Nasution A (2016) Government Decentralization Program in Indonesia. ADBI Working Paper. ADB, Tokyo.

North DC (1991) Institutions. J of Economic Perspectives 5(1):97-112. Doi: 10.1257/Jep.5.1.97

Oates WE (1972) Fiscal Federalism. Hartcourt Brace Jovanovich, New York.

Oxhorn P, Tulchin JS, Selee A (2004) Decentralization, Democratic Governance, and Civil Society in Comparative Perspective: Africa, Asia, and Latin America, Woodrow Wilson Center Press, Washington DC.

Pepinsky TB, Wihardja MM, (2010) Decentralization and Economic Performance in Indonesia. J of East Asian Studies 11(3).

Qian YY, Weingast BR (1997) Federalism as a commitment to preserving market incentives. J of Economic Perspectives 11(4):83-92. Doi: 10.1257/Jep.11.4.83

Rahmatunnisa M (2015) Jalan Terjal Kebijakan Desentralisasi di Indonesia pada Era Reformasi. J Ilmu Hukum 2(3):505-522. Doi: 10.22304/pjih.v2n3.a5

Rodriguez-Pose A, Kroijer A (2009) Fiscal Decentralization and Economic Growth in Central and Eastern Europe. Growth and Change 40(3):387-417. Doi: 10.1111/j.14682257.2009.00488.x

Roodman D (2009) How to do xtabond2: An introduction to difference and system GMM in Stata. Stata J 9(1):86-136. Doi: 10.1177/1536867x0900900106

Rubin DB (1987) Multiple Imputation for Nonresponse in Surveys. John Wiley \& Sons Inc, New York.

Rubin, DB (1996). Multiple imputation after 18+ years. J of the American Statistical Association 91(434):473-489. Doi: 10.1080/01621459.1996.10476908

Setiawan F, Aritenang AF (2019) The impact of fiscal decentralization on economic performance in Indonesia. IOP Conference Series: Earth and Environmental Science 340. Doi: $10.1088 / 1755-1315 / 340 / 1 / 012021$

Statistics of Indonesia (2007) Financial Statistics of Province Governance 2003-2006. BPSStatistics Indonesia, Jakarta.

Statistics of Indonesia (2008) Financial Statistics of Regency/Municipality Government 20062007. BPS-Statistics Indonesia, Jakarta.

Statistics of Indonesia (2009) Financial Statistics of Province Governance 2005-2008. BPSStatistics Indonesia, Jakarta.

Statistics of Indonesia (2010) Financial Statistics of Regency/Municipality Government 20082009. BPS-Statistics Indonesia, Jakarta. 
Statistics of Indonesia (2012) Financial Statistics of Province Governance 2008-2011. BPSStatistics Indonesia, Jakarta.

Statistics of Indonesia (2012) Financial Statistics of Regency/Municipality Government 20102011. BPS-Statistics Indonesia, Jakarta.

Statistics of Indonesia (2014) Financial Statistics of Regency/Municipality Government 20122013. BPS-Statistics Indonesia, Jakarta.

Statistics of Indonesia (2016) Financial Statistics of Province Governance 2012-2015. BPSStatistics Indonesia, Jakarta.

Statistics of Indonesia (2016) Financial Statistics of Regency/Municipality Government 20142015. BPS-Statistics Indonesia, Jakarta.

Statistics of Indonesia (2018) Financial Statistics of Regency/Municipality Government 20162017. BPS-Statistics Indonesia, Jakarta.

Statistics of Indonesia (2020) Financial Statistics of Province Governance 2016-2019. BPSStatistics Indonesia, Jakarta.

Statistics of Indonesia (2020) Financial Statistics of Regency/Municipality Government 20182019. BPS-Statistics Indonesia, Jakarta.

Statistics of Indonesia (2017) Gross Regional Domestic Product of Province in Indonesia by Expenditure 2004-2008. BPS-Statistics Indonesia, Jakarta.

Statistics of Indonesia (2007) Gross Regional Domestic Product of Province in Indonesia by Industry 2002-2006. BPS-Statistics Indonesia, Jakarta.

Statistics of Indonesia (2010) Gross Regional Domestic Product of Province in Indonesia by Industry 2006-2010. BPS-Statistics Indonesia, Jakarta.

Statistics of Indonesia (2015) Gross Regional Domestic Product of Province in Indonesia by Industry 2010-2014. BPS-Statistics Indonesia, Jakarta.

Statistics of Indonesia (2020) Gross Regional Domestic Product of Province in Indonesia by Industry 2015-2019. BPS-Statistics Indonesia, Jakarta.

Tiebout CM (1956) A Pure Theory of Local Expenditures. J of Political Economy, 64(October). Tiebout CM (1961) An Economic Theory of Fiscal Decentralization. NBER, New Jersey.

Tijaja J \& Mohammad F (2014) Industrial Policy in Indonesia: A Global Value Chain Perspective. ADB Economics Working Paper Series No. 411. ADBI, Tokyo.

Treisman D (1999) Political decentralization and economic reform: A game-theoretic analysis. American Journal of Political Science, 43(2):488-517. Doi: 10.2307/2991803

Treisman D (2007) The Architecture of Government: Rethinking Political Decentralization, Cambridge University Press.

Ubago-Martínez Y, Arzoz PP, Apezteguía, BI (2018) Does decentralization contribute to efficiency? Evidence from OECD countries. Applied Economics 50(7):726-742. Doi: 10.1080/00036846.2017.1340572

Wallich C, Bird RM, Ebel RD (1995) Decentralization of the Socialist State: Intergovernmental Finance in Transition Economies. The World Bank, Washington DC.

Weingast BR (1995) The Economic-Role of Political-Institutions - Market-Preserving Federalism and Economic-Development. J of Law Economics \& Organization 11(1): 1-31.

Yushkov A (2015) Fiscal decentralization and regional economic growth: Theory, empirics, and the Russian experience. Russian J of Economics 1(4):404-418. Doi: 10.1016/j.ruje.2016.02.004

Zhu X (2014) Comparison of Four Methods for Handing Missing Data in Longitudinal Data Analysis through a Simulation Study. Open Journal of Statistics 04:933-944. Doi: 10.4236/ojs.2014.411088

\section{List of abbreviations}

BKPM Badan Koordinasi Penanaman Modal (Investment Coordinating Board) 
BPS Badan Pusat Statistik (Statistics Indonesia)

DAU Dana Alokasi Umum (General Allocation Grant)

DAK Dana Alokasi Khusus (Special Allocation Grant)

DDI Domestic Direct Investment

FDI Foreign Direct Investment

GMM Generalized Method of Moment

GDP Gross Domestic Product

GRDP Gross Regional Domestic Product

GRDPPC Gross Regional Domestic Product per Capita

OLS Ordinary Least Square

SAR Special Administrative Region

\section{Availability of data and materials}

Data is available upon request to the corresponding author.

\section{Competing interests}

We declare that there are no competing interests regarding the writing of this paper.

\section{Funding}

The research was made possible under the MEXT Special Doctoral Program for Private Sector Development to Achieve Sustainable Economic Growth in Asia.

\section{Authors' contributions}

BW contributed to data construction, analysis, and drafting the manuscript. This is part of $\mathrm{PhD}$ dissertation supervised by $\mathrm{CO}$ who helped in improving the manuscript. All authors worked on the finalization of the manuscript.

\section{Acknowledgements}

We are grateful for the input from Prof. Shigeru Otsubo and Prof. Masakazu Someya at the Graduate School of International Development, Nagoya University. We are also grateful for comments from two referees. 
Appendix

Correlation Matrix

\begin{tabular}{lcccccr}
\hline VARIABLES & MAN & LCAP & FDI & DDI & RGDPPC & TRADE \\
\hline MAN & 1 & & & & & \\
LCAP & $0.18 * * *$ & 1 & & & & \\
FDI $I N D$ & $0.49 * * *$ & $0.25 * * *$ & 1 & & & \\
DDI $_{I N D}$ & $0.33 * * *$ & $0.29 * * *$ & $0.43 * * *$ & 1 & & \\
RGDPPC & $0.09 * *$ & $0.48 * * *$ & $0.37 * * *$ & $0.30 * * *$ & 1 & \\
TRADE & $0.27 * * *$ & $0.14 * * *$ & $0.30 * * *$ & $0.23 * * *$ & $0.39 * * *$ & 1 \\
INFLATION & -0.03 & -0.01 & $-0.16 * * *$ & $-0.17 * * *$ & $-0.13 * * *$ & -0.04 \\
\hline N & 544 & & & & & \\
\hline
\end{tabular}

Note: $* \mathrm{p}<0.1, * * \mathrm{p}<0.05, * * * \mathrm{p}<0.01$ 
Table 5. Robustness Test under Different Estimation Methods

\begin{tabular}{|c|c|c|c|c|c|c|c|c|}
\hline \multirow{3}{*}{ VARIABLES } & \multicolumn{8}{|c|}{ DEPENDENT VARIABLE: MANUFACTURING } \\
\hline & \multicolumn{2}{|c|}{ OLS } & \multicolumn{2}{|c|}{ FE-OLS } & \multicolumn{2}{|c|}{ Diff. GMM } & \multicolumn{2}{|c|}{ System GMM } \\
\hline & $(1)$ & $(2)$ & (3) & $(4)$ & $(5)$ & $(6)$ & $(7)$ & $(8)$ \\
\hline $\mathrm{MAN}_{(\mathrm{t}-1)}$ & $\begin{array}{r}0.963 * * * \\
(0.015)\end{array}$ & $\begin{array}{r}0.969 * * * \\
(0.014)\end{array}$ & $\begin{array}{r}0.888 * * * \\
(0.024)\end{array}$ & $\begin{array}{r}0.889 * * * \\
(0.023)\end{array}$ & $\begin{array}{r}0.964 * * * \\
(0.050)\end{array}$ & $\begin{array}{r}0.974 * * * \\
(0.057)\end{array}$ & $\begin{array}{r}0.921 * * * \\
(0.027)\end{array}$ & $\begin{array}{r}0.953 * * * \\
(0.020)\end{array}$ \\
\hline LCAP & $\begin{array}{r}0.096 * * * \\
(0.033)\end{array}$ & $\begin{array}{r}0.099 * * \\
(0.042)\end{array}$ & $\begin{array}{r}0.018 \\
(0.033)\end{array}$ & $\begin{array}{r}0.001 \\
(0.037)\end{array}$ & $\begin{array}{r}0.116 \\
(0.074)\end{array}$ & $\begin{array}{l}0.107 * \\
(0.064)\end{array}$ & $\begin{array}{r}0.140 * * * \\
(0.053)\end{array}$ & $\begin{array}{r}0.124 * * * \\
(0.041)\end{array}$ \\
\hline RGDPPC & $\begin{array}{r}-0.529 \\
(1.322)\end{array}$ & $\begin{array}{r}-1.047 \\
(1.266)\end{array}$ & $\begin{array}{r}1.102 \\
(4.103)\end{array}$ & $\begin{array}{r}1.088 \\
(3.833)\end{array}$ & $\begin{array}{r}1.002 \\
(12.900)\end{array}$ & $\begin{array}{r}0.987 \\
(13.403)\end{array}$ & $\begin{array}{r}0.837 \\
(1.415)\end{array}$ & $\begin{array}{r}-0.615 \\
(1.198)\end{array}$ \\
\hline RGDPPC $^{2}$ & $\begin{array}{r}0.010 \\
(0.053)\end{array}$ & $\begin{array}{r}0.032 \\
(0.051)\end{array}$ & $\begin{array}{r}-0.058 \\
(0.169)\end{array}$ & $\begin{array}{r}-0.054 \\
(0.158)\end{array}$ & $\begin{array}{r}-0.117 \\
(0.518)\end{array}$ & $\begin{array}{r}-0.112 \\
(0.537)\end{array}$ & $\begin{array}{r}-0.051 \\
(0.056)\end{array}$ & $\begin{array}{r}0.011 \\
(0.047)\end{array}$ \\
\hline $\operatorname{TRADE}_{(t-1)}$ & $\begin{array}{r}0.000 \\
(0.001)\end{array}$ & $\begin{array}{r}0.000 \\
(0.001)\end{array}$ & $\begin{array}{r}0.002 \\
(0.002)\end{array}$ & $\begin{array}{r}0.002 \\
(0.002)\end{array}$ & $\begin{array}{r}0.005 \\
(0.004)\end{array}$ & $\begin{array}{r}0.005 \\
(0.004)\end{array}$ & $\begin{array}{r}0.003^{* *} \\
(0.002)\end{array}$ & $\begin{array}{l}0.002 * \\
(0.001)\end{array}$ \\
\hline INFLATION & $\begin{array}{r}0.005 \\
(0.010)\end{array}$ & $\begin{array}{r}0.005 \\
(0.010)\end{array}$ & $\begin{array}{r}0.055^{* *} \\
(0.025)\end{array}$ & $\begin{array}{r}0.054 * * \\
(0.025)\end{array}$ & $\begin{array}{r}0.071 * * \\
(0.030)\end{array}$ & $\begin{array}{r}0.071^{* * *} * \\
(0.027)\end{array}$ & $\begin{array}{r}0.055^{* *} \\
(0.026)\end{array}$ & $\begin{array}{r}0.062 * * \\
(0.024)\end{array}$ \\
\hline FDI $I N D$ & $\begin{array}{r}0.152 * * * \\
(0.047)\end{array}$ & & $\begin{array}{r}0.172 * * \\
(0.068)\end{array}$ & & $\begin{array}{r}0.209 * * \\
(0.081)\end{array}$ & & $\begin{array}{r}0.260 * * * \\
(0.100)\end{array}$ & \\
\hline $\mathrm{DDI}_{I N D}$ & & $\begin{array}{r}0.002 \\
(0.010)\end{array}$ & & $\begin{array}{r}-0.034 \\
(0.024)\end{array}$ & & $\begin{array}{r}-0.014 \\
(0.011)\end{array}$ & & $\begin{array}{r}-0.005 \\
(0.017)\end{array}$ \\
\hline LCAP x FDI IND & $\begin{array}{r}0.002 \\
(0.010)\end{array}$ & & $\begin{array}{r}-0.034 \\
(0.024)\end{array}$ & & $\begin{array}{r}-0.014 \\
(0.011)\end{array}$ & & $\begin{array}{r}-0.005 \\
(0.017)\end{array}$ & \\
\hline LCAP x DDI IND & & $\begin{array}{r}-0.006 \\
(0.011)\end{array}$ & & $\begin{array}{r}-0.027 \\
(0.019)\end{array}$ & & $\begin{array}{r}-0.011 \\
(0.016)\end{array}$ & & $\begin{array}{r}-0.004 \\
(0.011)\end{array}$ \\
\hline CONS & $\begin{array}{r}4.910 \\
(8.226) \\
\end{array}$ & $\begin{array}{r}7.839 \\
(7.963) \\
\end{array}$ & $\begin{array}{r}-3.526 \\
(24.901) \\
\end{array}$ & $\begin{array}{r}-3.846 \\
(23.209) \\
\end{array}$ & & & $\begin{array}{r}-2.601 \\
(8.992) \\
\end{array}$ & $\begin{array}{r}5.838 \\
(7.711) \\
\end{array}$ \\
\hline Province FE & No & No & Yes & Yes & Yes & Yes & Yes & Yes \\
\hline Year FE & No & No & Yes & Yes & Yes & Yes & Yes & Yes \\
\hline Observations & 544 & 544 & 544 & 544 & 544 & 544 & 544 & 544 \\
\hline Provinces & 34 & 34 & 34 & 34 & 34 & 34 & 34 & 34 \\
\hline Adj. $R^{2}$ & 0.985 & 0.985 & 0.824 & 0.823 & & & & \\
\hline F-stat. & $3925 * * *$ & $3821 * * *$ & $1570 * * *$ & $1822 * * *$ & & & & \\
\hline Instruments & & & & & 39 & 39 & 41 & 41 \\
\hline AR-1 & & & & & 0.018 & 0.014 & 0.022 & 0.016 \\
\hline AR-2 & & & & & 0.281 & 0.354 & 0.275 & 0.582 \\
\hline Hansen (P-val) & & & & & 0.169 & 0.357 & 0.927 & 0.985 \\
\hline $\begin{aligned} \text { Note: - } & \text { Robust st } \\
\text { - } & \text { AR-1 an } \\
& \text { diagnosti } \\
\text { - } & \text { Hansen } \mathrm{J} \\
& \text { value is } r\end{aligned}$ & $\begin{array}{l}\text { dard error i } \\
\text { AR-2 deno } \\
\text { for dynami } \\
\text { t calculate } \\
\text { rted. }\end{array}$ & $\begin{array}{l}\text { parenthese } \\
\text { es Arellano } \\
\text { panel data } \\
\text { overidenti }\end{array}$ & $\begin{array}{l}* \mathrm{p}<0.1, * \\
\text { Bond test } \\
\text { stimation } \mathrm{i} . \\
\text { ing restrict }\end{array}$ & $\begin{array}{l}\mathrm{p}<0.05 \text {, } \\
\text { ith } \mathrm{p} \text {-value } \\
\text { ons that occ }\end{array}$ & $\begin{array}{l}* \mathrm{p}<0.01 \\
\text { results are }\end{array}$ & reported. & hey are the & $\begin{array}{l}\text { necessary } \\
\text { uments. P- }\end{array}$ \\
\hline
\end{tabular}


Figures

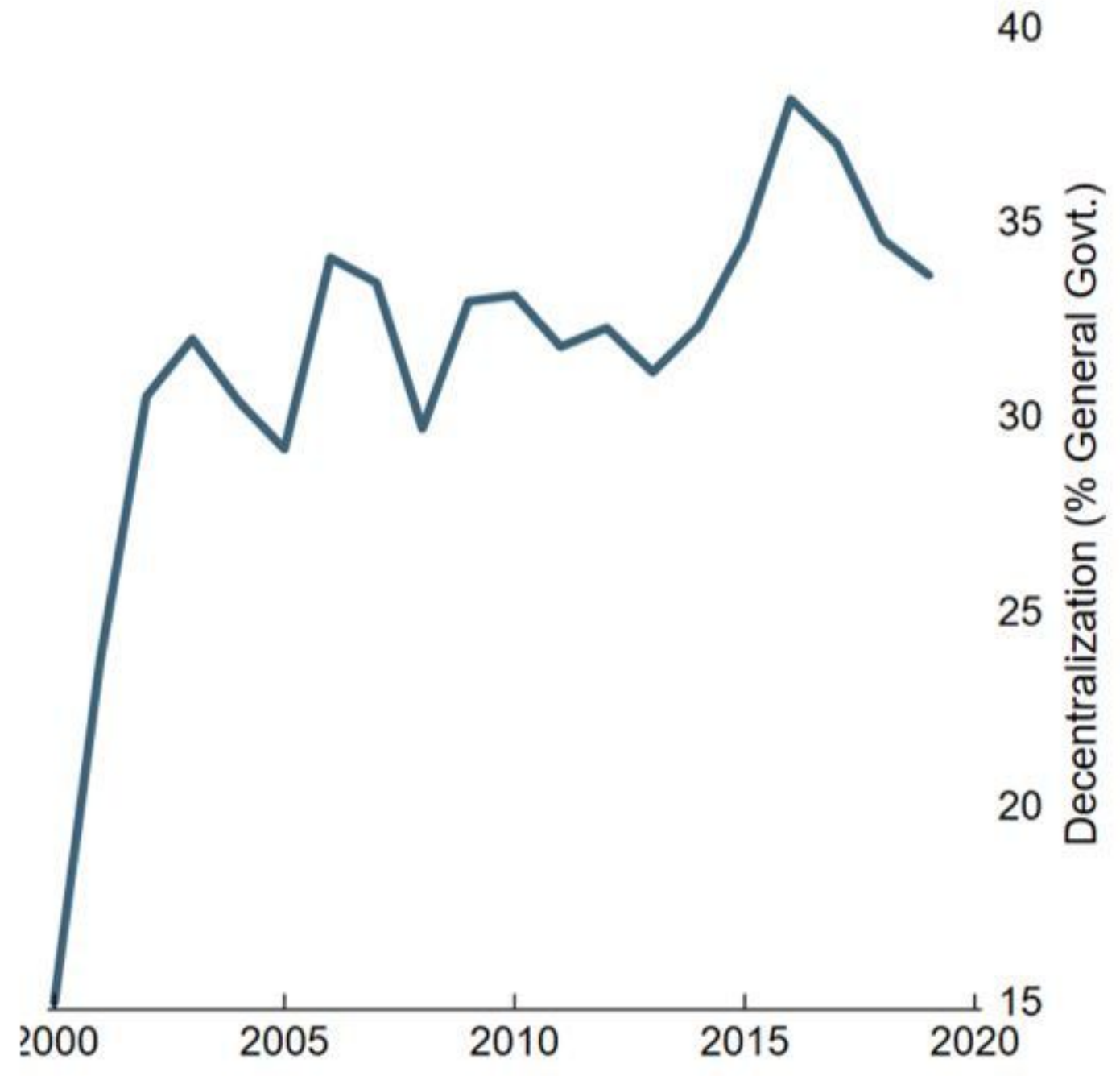

Source: MOF 2020

Figure 1

Indonesia's Fiscal Decentralization share 2000 - 2019 